\title{
Kształtowanie się tożsamości płciowej w kontekście edukacji seksualnej
}

\author{
Formation of Gender Identity
} in the Context of Sex Education

\begin{abstract}
ABSTRAKT
Psychologia, a zwłaszcza psychologia rozwojowa, wykazała, że dzieci rodza się jako osoby seksualne, a ich seksualność rozwija się etapowo, co jest zwiqzane z ogólnym rozwojem dziecka i z zadaniami zwiqzanymi z rozwojem. Etapy rozwoju seksualnego (rozwoju psychoseksualnego według Zygmunta Freuda) zostały przedstawione w szczegółowy sposób w celu wyjaśnienia uprzednio wspomnianej konieczności wczesnego rozpoczęcia edukacji seksualnej i wykazania, że konkretne treści/informacje, umiejętności i postawy sq przekazywane w powiqzaniu z rozwojem dziecka. W optymalnej sytuacji poszczególne zagadnienia sq wprowadzane zanim dziecko osiqgnie odpowiedni etap rozwoju, tak aby przygotować je do zmian, które niebawem maja nastapić (na przykład dziewczynki powinny wiedzieć o miesiq̨czkowaniu zanim wystąpi pierwsza miesiqczka).
\end{abstract}

\section{ABSTRACT}

Psychology, particularly developmental psychology, has shown that a child is born as a sexual person, and his/her sexuality develops in stages associated with general child development and the tasks re-

Articles and dissertations
KEYWORDS

identity, gender, sexual education, stereotype, sexual development

SŁOWA KLUCZOWE tożsamość, płeć, edukacja seksualna, stereotyp, rozwój seksualny

SPI Vol. 20, 2017/2

ISSN 2450-5358

e-ISSN 2450-5366

DOI: 10.12775/SPI.2017.2.009

Artykuły i rozprawy 
lated to development. The stages of sexual development (psychosexual development according to Sigmund Freud) were presented in detail in order to clarify the need for an early start sex education and to demonstrate that specific content/information, skills and attitudes are passed on in connection with the development of the child. The optimal situation is when the individual issues are introduced before the child reaches the appropriate stage of development, so as to prepare them for the changes that will soon have to occur (for example, girls should know about menstruation occurs before menarche).

\section{Seksualnośćc czlowieka - problem definicji i interdyscyplinarne podejście}

Intencją niniejszego tekstu jest próba przyjrzenia się standardom edukacji seksualnej w Europie w kontekście teorii, definicji rozwoju psychoseksualnego dziecka i teorii seksualności. Na początku należy przywołać dokument o standardach edukacji seksualnej w Europie, pt. Standardy edukacji seksualnej w Europie. Podstawowe zalecenia dla decydentów oraz specjalistów zajmujacych się edukacja $i$ zdrowiem ${ }^{1}$, autorstwa Biura Regionalnego Światowej Organizacji Zdrowia dla Europy i Federalnego Biura ds. Edukacji Zdrowotnej (BZgA). Dokument ten powstał jako odpowiedź na konieczność stworzenia odpowiednich standardów edukacji seksualnej ${ }^{2}$. Ma on za zadanie wprowadzenie całościowej wiedzy na temat rozumienia seksualności.

Najbardziej wszechstronna definicja seksualności została opublikowana w 2005 roku: „Seksualność jest podstawowym elementem bycia człowiekiem przez całe życie, obejmującym seks, płciową identyfikacje i rolę, orientację seksualną, erotyzm, pożądanie, intymność i reprodukcję. Seksualność jest doświadczana i wyrażana w myślach, fantazjach przeżyciach, przekonaniach, wartościach, zachowaniach, rolach i związkach”3.

$1 \quad$ Standardy edukacji seksualnej w Europie. Podstawowe zalecenia dla decydentów oraz specjalistów zajmujących się edukacja $i$ zdrowiem, <http://www.federa.org. pl/dokumenty_pdf/edukacja/WHO_BZgA_Standardy_edukacji_seksualnej.pdf> [dostęp: 12.10.2016].

2 Tamże, s. 5.

3 Z. Lew-Starowicz, Seksuologia psychospoteczna, w: Podstawy seksuologii, red. Z. Lew-Starowcz, V. Skrzypulec, Warszawa 2015, s. 25. 
Współcześnie coraz częściej przyjmuje się podejście holistyczne do seksualności. Opiera się ono na rozumieniu seksualności jako wymiaru człowieczeństwa i potencjalnie może pomóc dzieciom i młodym osobom w rozwinięciu podstawowych umiejętności umożliwiających im samookreślenie ich seksualności i ich związków na różnych etapach rozwoju ${ }^{4}$.

Podejście to ma swoje korzenie w licznych pracach naukowych badaczy takich badaczy jak: Richard von Kraft-Ebing, Havelock E1lis i Magnus Hirschfeld. Seksuologia zawsze miała cele społeczne. W XIX i na początku XX wieku często dążyła do zwiększenia tolerancji dla odmiennych form ludzkiej seksualności 5 .

Zanim przejdę do omawiania kształtowania się tożsamości seksualnej, warto przywołać szersze uwarunkowania seksualności. Na seksualność ma wpływ szereg czynników warunkujących, od czynników biologicznych, psychologicznych, społecznych aż do religijnych. Seksualność w encyklopediach i słownikach określana jest jako „wrodzona naturalna potrzeba i funkcja organizmu ludzkiego, podobnie jak oddychanie, procesy trawienne i inne ${ }^{6}$.

Kazimierz Imieliński podkreśla jednocześnie, że jest ona „czymś więcej niż biologicznie uwarunkowaną funkcją, obejmuje bowiem wszelkie związane z popędem seksualnym sposoby przeżywania i zachowania, wynikające $\mathrm{z}$ faktu życia wśród społeczeństwa" . Autor ten dodaje również, że nie należy wyjaśniać i opisywać seksualności tylko w aspekcie biologicznym, gdyż mogłoby to skutkować oderwaniem tej strefy życia od kultury, zasad społecznych, potrzeb psychicznych oraz systemu norm.

O seksualności należy mówić w jak najszerszym zakresie. Wynika to $\mathrm{z}$ faktu, że jest to nauka o charakterze interdyscyplinarnym. Dziedzina ta opiera się na naukach medycznych (psychiatria, ginekologia), biologicznych (endokrynologia, fizjologia, anatomia) oraz społecznych (psychologia, pedagogika, socjologia) ${ }^{8}$.

4 Tamże, s. 5.

5 S. Seidman, Spoteczne tworzenie seksualności, tłum. P. Tomanek, Warszawa 2012, s. 49.

6 M. Beisert, W poszukiwaniu modelu seksualności cztowieka, w: Seksualność w cyklu życia człowieka, red. M. Beisert, Warszawa 2006, s. 8.

7 K. Imielinski (red.), Seksuologia - zarys encyklopedyczny, Warszawa 1985, s. 344.

8 I. Obuchowska, A. Jaczewski, Rozwój erotyczny, Warszawa 2002, s. 12. 
Z tego właśnie powodu przedmiotem dalszych rozważań będzie bardzo szeroki zakres elementów, które składają się na seksualność człowieka. Wielu autorów podkreśla, że prawidłowo przeżywana i rozumiana seksualność uwarunkowana jest trzema głównymi czynnikami: biologicznymi, psychicznymi i społecznymi ${ }^{9}$. Maria Beisert nazywa te obszary: psyche, soma i polis ${ }^{10}$.

Obecnie w badaniach nad seksualnością najwięcej uwagi poświęca się następującym czynnikom:

- biologicznym (genetyka, hormony, neuroprzekaźniki, anatomia i fizjologia seksualna);

- psychicznym (potrzeby, oczekiwania, postawy, motywacje zachowań seksualnych, obraz własnej osoby, twórczość erotyczna, osobowość, relacje partnerskie, rozwój psychoseksualny);

- społecznym (normy, edukacja, mody, stereotypy, przesądy, role płciowe, sztuka erotyczna i pornografia, gender studies, pseudoseksuologia, uwarunkowania rodzinne i środowiskowe, seksozofie społeczne, relacje partnerskie $)^{11}$.

Ulrich Beer podkreśla, że „zadaniem każdego człowieka jest humanizacja własnej seksualności, włączenie jej we własną osobowość, dopasowywanie się do niej i adaptacja jej do siebie, by w końcu stanowiły jedność, by były jednym i tym samym"12. Konieczna do tego jest akceptacja własnego ciała i płci. Podobnie odnosi się do tego K. Imieliński, mówiąc, że seks to istotna forma wyrażania się całej osobowości człowieka ${ }^{13}$.

\section{Etapy rozwoju seksualności}

Seksualność podlega zmianom, na które na każdym etapie rozwojowym człowieka wpływają dwa komponenty. Widoczny staje się zmienny udział poszczególnych czynników, w zależności od fazy rozwojowej - proporcje oddziaływań, wprowadzenie nowych,

9 K. Imieliński, Cztowiek i seks, Warszawa 1986, s. 36; K. Imieliński (red.), Seksuologia - zarys encyklopedyczny, dz. cyt., s. 343; M. Beisert, $W$ poszukiwaniu modelu seksualności cztowieka, w: Seksualność w cyklu życia cztowieka, dz. cyt., s. 8.

$10 \quad$ M. Beisert, $W$ poszukiwaniu modelu seksualności człowieka, dz. cyt. s. 15.

11 Z. Lew-Starowicz, Seksuologia psychospoteczna, dz. cyt., s 26.

12 U. Beer, A jednak mitość..., tłum. B. Kocowska, Wrocław 1991, s. 25.

13 K. Imieliński, Cztowiek i seks, dz. cyt., s. 16. 
typowych dla danej fazy czynników i zanikanie innych, typowych dla fazy wcześniejszej ${ }^{14}$.

W przywołanym na wstępie dokumencie Biura Regionalnego Światowej Organizacji Zdrowia dla Europy i Federalnego Biura ds. Edukacji Zdrowotnej dowiedziono konieczności wczesnego rozpoczęcia wychowania seksualnego, jak również wyjaśniono dlaczego poszczególne zagadnienia powinny być omawiane $\mathrm{w}$ danym okresie życia dziecka ${ }^{15}$.

W przypadku kiedy mówi się o zachowaniach seksualnych dzieci i młodych osób istotne jest, aby mieć na uwadze, że seksualność jest różna u dzieci i osób dorosłych oraz że dorośli nie powinni oceniać zachowań dzieci i młodzieży z własnej perspektywy ${ }^{16}$.

Ogólnie mówiąc, w ciągu pierwszych sześciu lat życia dzieci w gwałtowny sposób rozwijają się, przechodząc od całkowitej zależności do częściowej niezależności. Zaczynają postrzegać własne ciało. Dzieci mają uczucia seksualne nawet we wczesnym okresie niemowlęcym. Między drugim a trzecim rokiem życia odkrywają fizyczne różnice między płciami. W tym czasie zaczynają odkrywać własne ciało (masturbacja we wczesnym dzieciństwie, autostymulacja) i mogą także próbować badać ciała swoich przyjaciół (zabawa w lekarza). Dzieci eksperymentując zdobywają informacje o swoim środowisku, a nauka seksualności niczym nie różni się w tym zakresie. Na podstawie wyników licznych badań obserwacyjnych zidentyfikowano powszechne zachowania seksualne u dzieci, a równocześnie stwierdzono, że tego typu zachowania są normalne ${ }^{17}$.

Ze względu na temat artykułu skoncentruje się tylko na pogłębionej analizie rozwoju psychoseksualnego według Zygmunta Freuda, który jako pierwszy odkrył i opracował teoretyczne podstawy jego rozwoju, opisał znaczenie wczesnego dzieciństwa dla kształtowania się osobowości i wystąpienia zaburzeń psychicznych. Opierał się jednak na obserwacjach pochodzących z psychoanaliz pacjentów będących w okresie późnego dojrzewania lub osób dorosłych. Freud nie

14 M. Beisert, W poszukiwaniu modelu seksualności cztorwieka, dz. cyt., s. 13.

15 Standardy edukacji seksualnej w Europie. Podstawowe zalecenia dla decydentów oraz specjalistów zajmujących się edukacją i zdrowiem, <http://www.federa.org. pl/dokumenty_pdf/edukacja/WHO_BZgA_Standardy_edukacji_seksualnej.pdf>, s. 22 [dostęp: 12.10.2016].

16 Tamże.

17 Tamże, s. 23. 
prowadził systematycznych badań ani zdrowych, ani chorych dzieci. Inni psychoanalitycy zajmujący się dziećmi uzupełnili i rozwinęli teorię Freuda. Co więcej, w rozważaniach nad genezą objawów psychopatologicznych Freud skupiał tylko na kompleksie Edypa. Według niego nerwica osób pozostających w edypalnym trójkącie wynika z niemożności pogodzenia konkurencyjnych, nieświadomych uczuć erotycznych i agresji wobec rodziców. Współcześnie uważa się, że teoria ta tylko częściowo tłumaczy genezę objawów psychopatologicznych ${ }^{18}$.

Stadia opisane przez Freuda dają bardzo bogatą i aktualną wiedzę na temat rozwoju seksualnego ${ }^{19}$. Należy także nawiązać do teorii rozwoju dziecka Margaret Mahler, Erika H. Eriksona i Jeana Piageta, którzy komentując daną fazę rozwojową, stworzyli podwaliny do teorii rozwoju dziecka. Freud uzupełnił ją tylko o rozwój ról płciowych.

Stadium pierwsze. Rozwój seksualności dziecka rozpoczyna się już w momencie narodzin. Niemowlęta skupiają się całkowicie na własnych zmysłach: dotyku, słuchu, wzroku, smaku i zapachu. Dzięki zmysłom mogą doświadczać uczuć komfortu i bezpieczeństwa. Niezwykle istotne jest przytulanie i obdarzanie pieszczotami własnego dziecka $z$ uwagi na fakt, że dzięki temu tworzone są fundamenty jego zdrowego, właściwego rozwoju społecznego i emocjonalnego ${ }^{20}$. Wzmiankowany dokument widzi w tym racjonalne uzasadnienie potrzeby prowadzenia edukacji seksualnej. Pokrywa się to $\mathrm{z}$ teorią fazy oralnej według Freuda, która zakłada, że stadium oralne trwa do około osiemnastego miesiąca życia - w tym najwcześniejszym etapie potrzeby dziecka, jego ekspresja i sposoby jej wyrażania są pierwotnie skupione na ustach, wargach, języku i innych organach związanych z ustami. Oralne doznania są skorelowane $z$ takimi uczuciami jak głód, pragnienie, dotykowe doznania wynikające $z$ kontaktu $z$ piersią matki lub jej substytutem oraz wrażenia związane z przelykaniem i nasyceniem. Stany oralnego napięcia prowadzą do poszukiwania oralnej gratyfika-

18 B.J. Sadock, V.A. Sadock, Kaplan and Sadock's Pocket Handbook of Clinical Psychiatry, Philadelphia (PA) 2010, s. 180-205.

19 Freud nie używa w swoich pracach terminu „rozwoju ról płciowych”, posługuje się terminem „rozwój psychoseksualny”.

20 Standardy edukacji seksualnej w Europie. Podstawowe zalecenia dla decydentów oraz specjalistów zajmujacych się edukacja $i$ zdrowiem, s. 24, <http://www. federa.org.pl/dokumenty_pdf/edukacja/WHO_BZgA_Standardy_edukacji_seksualnej.pdf> [dostęp: 12.10.2016]. 
cji. Psychologicznym celem tej fazy jest ustalenie ufnej relacji zależności od osoby sprawującej opiekę, co skutkuje możliwością wyrażania libidinalnych pragnień, bez nadmiernych konfliktów lub ambiwalencji wynikających z oralnych, sadystycznych pragnien ${ }^{21}$.

Tutaj chciałbym zaznaczyć, że - w przeciwieństwie do Mahler - Freud, Erikson i Piaget na podstawie obserwacji stwierdzili, iż w relacji matka-dziecko strony pozostają pod silnym wrażeniem współzależności i komplementarności (a nie autyzmu czy symbiozy), tworząc podstawy rozwoju relacji i języka. Piaget i inni podkreślają, że noworodek usiłuje aktywnie manipulować nieożywionym otoczeniem. Uzupełnia to teorię Freuda założeniem, że motywacja noworodka i małego dziecka służy nie tylko łagodzeniu napięć popędowych i zaspokajaniu potrzeb oralnych, analnych i fallicznych.

Stadium drugie. Małe dzieci w wieku od dwóch do trzech lat stają się świadome samych siebie i swoich ciał (ciekawość/badanie własnego ciała). Uczą się także, że różnią się od innych dzieci i od osób dorosłych (rozwijają swoją tożsamość), że istnieją chłopcy i dziewczynki (dochodzi u nich do rozwoju tożsamości płciowej), stają się bardzo ciekawe własnego ciała, a także osób z ich otoczenia. Często badają w dokładny sposób swoje ciała i narządy płciowe, a także pokazują je innym dzieciom i osobom dorosłym, rozmyślnie ich dotykają, ponieważ sprawia im to przyjemność. Już w tym wieku widać u nich dużą potrzebę kontaktu fizycznego.

$\mathrm{Na}$ tym etapie pojawia się zwiększona ambiwalencja wobec rodziców, będąca wynikiem treningu czystości (dawania lub zatrzymywania stolca). Zachodzą wówczas procesy separacji i indywiduacji. „Analny erotyzm” polega na czerpaniu przyjemności zarówno z zatrzymywania stolca, jak i z prezentowania go rodzicom oraz z doznań płynących w trakcie defekacji. Faza analna staje się okresem budowania niezależności i oddzielania się od rodziców. Jej celem jest umiejętność panowania nad zwieraczami, utrzymanie równowagi między nadmierną kontrolą a jej brakiem. Jest to zbieżne z wysiłkami dążącymi do osiągnięcia autonomii i niezależności, bez nadmiernego wstydu, ale też i bez zwątpienia we własne umiejętności ${ }^{22}$.

21 P. Drozdowski, A. Kokoszka, Podstawowe pojęcia psychoanalizy, w: Wprowadzenie do psychoterapii, red. P. Drozdowski, A. Kokoszka, Kraków 1993, s. 63-72.

22 Tamże. 
Uzupełniając prace Freuda i Mahler, inni twórcy teorii rozwoju dziecka dowiedli, że poważne trudności w relacji matka-dziecko przyczyniają się do patologicznych cech charakteru i zaburzeń tożsamości płciowej. Opiekunowie pełni gniewu, niezadowolenia i narcyzmu wychowują pełne gniewu i egoizmu dzieci i dorosłych, którzy nie potrafią znieść frustracji rozczarowań w związkach z innymi. Wykazują poważne zaburzenia osobowości.

Zanim przejdę do trzeciej fazy, czy - jak pisze Freud - trzeciego stadium rozwoju psychoseksualnego (stadium falliczne), opiszę rzadko omawiane w literaturze stadium uretralne. Obejmuje ono fazę przejściową pomiędzy stadium analnym a fallicznym. Istotne staje się w nim nabywanie kontroli nad oddawaniem moczu. Zaczyna się wówczas kształtować poczucie tożsamości seksualnej, wynikające z naśladowania sposobu oddawania moczu przez rodzica tej samej płci.

Stadium falliczne to okres pomiędzy trzecim a piątym rokiem życia. Na tym etapie wzrasta zainteresowanie dziecka kwestiami seksualności. Kolejną sferą erogenną, która zaczyna dominować, stają się zewnętrzne narządy płciowe - penis i łechtaczka oraz doznania płynące $z$ ich stymulacji. Penis staje się organem budzącym zainteresowanie dzieci obojga płci. Brak penisa jest postrzegany jako pewien niedostatek (kastracja). U dzieci pojawiają się w tym czasie nieświadome fantazje na temat kontaktów seksualnych $\mathrm{z}$ rodzicem przeciwnej płci. Poczucie zagrożenia i kary ze strony rodzica tej samej płci przyczynia się do powstania tzw. lęków kastracyjnych. Lęk kastracyjny związany jest $z$ poczuciem winy wynikającym $z$ edypalnych pragnień - pragnień kontaktu z rodzicem przeciwnej płci i z podejmowania rywalizacji z rodzicem tej samej płci ${ }^{23}$. Warto tutaj dodać, że współcześni naukowcy uzupełnili koncepcję Freuda. Dzieci obu płci odkrywają wiedzę o swoich narządach płciowych już w drugim roku życia. Dzięki prawidłowemu wzmocnieniu ze strony rodziców zaczynają poprawnie identyfikować się z własną płcią. Zazdrość o prącie nie jest powszechna ani nie jest normą.

Dzieci w tym wieku mają lepszy kontakt z rówieśnikami, uczą się zasad społecznych, wiedzą, że osoby dorosłe nie akceptują publicznego eksponowania własnego ciała, natomiast jeśli chodzi o badanie własnego ciała i ciała innych osób, to pojawia się ono w kontekście zabawy.

23 Tamże. 
Czwarte stadium to stadium latencji - pojawia się około piątego/szóstego roku życia, trwa do około jedenastego/trzynastego roku i jest okresem względnego uspokojenia lub braku aktywności seksualnej w wyniku powstania pod koniec fazy edypalnej superego i dojrzewania funkcji ego. W tym okresie pojawiają się homoseksualne związki u chłopców i dziewcząt oraz sublimacja libidinalnych i agresywnych energii w uczenie się, zabawę, socjalizację. Najważniejszym celem tego okresu jest dalsza integracja edypalnych identyfikacji i konsolidacja tożsamości seksualnej oraz ról seksualnych. Ma miejsce poszerzenie kontaktów z innymi ważnymi osobami spoza rodziny, które mają wpływ na rozwój identyfikacji seksualnej. Dzięki wyciszeniu libidinalnych pragnień dziecko kształtuje swą socjalizację oraz osiąga umiejętności wpływające na jego separację i rozwój autonomii ${ }^{24}$.

W przeciwieństwie do Freuda sądzi się obecnie, że latencja (wiek szkolny albo środkowa faza dzieciństwa) jest przede wszystkim skutkiem zmian w ośrodkowym układzie nerwowym (OUN), w mniejszym zaś stopniu zależy od względnego wyciszenia i sublimacji popędu seksualnego. Zmiany w OUN znajdują odzwierciedlenie w rozwoju procesów percepcyjno-czuciowo-motorycznych i myślowych w okresie od szóstego do ósmego roku życia dziecka. W pracach Piageta odpowiada to przejściu do okresu operacji konkretnych. Dzieci w okresie latencji są zdolne do szybkiego uczenia się, niezależnego funkcjonowania i uspołeczniania. Kształtują związki przyjacielskie w warunkach mniejszej zależności od rodziców i mniejszego zaangażowania w wewnątrzrodzinne rywalizacje edypalne. Sądzi się dzisiaj, że rozwój superego jest dłuższy, bardziej stopniowy i mniej zależny od rozwiązania konfliktu edypalnego ${ }^{25}$.

Ostanim stadium rozwoju jest stadium genitalne. Obejmuje ono okres od jedenastego/trzynastego roku życia do młodej dorosłości. Fizjologiczne dojrzewanie narządów płciowych i związanego z tym systemu hormonalnego prowadzi do intensyfikacji popędów, głównie libidinalnych. Zjawisko to powoduje regresję organizacji osobowości, co zdradza konflikty z poprzednich stadiów

24 Tamże.

25 B.J. Sadock, V.A. Sadock, Kaplan and Sadock's Pocket Handbook of Clinical Psychiatry, dz. cyt., s. 180-205. 
i daje możliwość ich rozwiązania w celu osiągnięcia dojrzałości seksualnej oraz dorosłej tożsamości ${ }^{26}$. Charakterystyczny dla tego stadium jest fakt, że dzieci zadają mniej pytań dotyczących seksu, co nie oznacza, iż są w mniejszym stopniu zainteresowane tym tematem.

Rozwój seksualny człowieka opisuje także teoria relacji z obiektem według Kernberga, według której podkreśla się, że poza czynnikami biologicznymi istotna staje się relacja z obiektem (ważną postacią - z reguły matką lub ojcem) we wczesnym dzieciństwie (szósty/ siódmy rok życia). Zdaniem Kernberga, rozwój przebiega w zależności od płci dziecka, jednak posiada pewne cechy wspólne - elementy seksualności, takie jak miłość (czułość) i agresja. Agresję zalicza się do pierwotnych afektów, oznacza ona siłę realizującą zamiar, dążenie do celu, pokonywanie przeszkód. Drugi element (miłość czy czułość) jest pochodną dążenia do przyjemności otrzymywanej w bezpiecznym i pełnym miłości kontakcie $\mathrm{z}$ obiektem. W okresie edypalnym integracja agresywności i miłości stanowi główny temat czy zadania dziecka, by po intensywnej dezintegracji okresu dorastania osiągnąć nowy etap zintegrowany ${ }^{27}$.

Rozwój psychoseksualny w ujęciu Freuda to przechodzenie wraz z rozwojem przez różne fazy, w których swój prymat mają różne sfery erogenne razem z zaspokojeniem płynącym z tych źródeł. Seksualność można podzielić na fazę pregenitalną i genitalną, z czego pierwsza obejmuje wszystkie fazy rozwoju seksualnego aż do okresu latencji. Freud wobec seksualności dziecięcej używał określenia „polimorficznej perwersyjności”, gdyż aktywność seksualna w tym czasie wyklucza zaangażowanie popędu w rozmnażanie ${ }^{28}$.

\section{Tożsamość seksualna w kontekstach edukacyinych}

Należy zwrócić uwagę, że prawidłowy rozwój psychoseksualny dziecka i adolescenta należy rozpatrywać w aspektach: biologicznym, psychologicznymi i społecznym, do czego nawiązano na początku

26 P. Drozdowski, A. Kokoszka, Podstawowe pojęcia psychoanalizy, dz. cyt., s. 63-72.

27 Por. O.F. Kernberg, Związi mitosne. Norma i patologia, tłum. E. Lipska, Poznań 1998.

28 Por. Z. Freud, Życie seksualne, tłum. R. Reszke, Warszawa 1999. 
artykułu, gdzie opisano czynniki wpływające na seksualność człowieka. Fizjologiczny przebieg tego rozwoju daje możliwość prawidłowego funkcjonowania dziecka, a następnie adolescenta w życiu dorosłym ze wszystkimi jego konsekwencjami. Dlatego tak ważna jest nie tylko znajomość poszczególnych etapów rozwoju psychoseksualnego, ale przede wszystkim rozumienie związanych z nimi zachowań dziecka czy dorastającego.

W nawiązaniu natomiast do standardów edukacji seksualnej, tak opisane i wyjaśnione stadia ujmują ją w sposób całościowy. Mając to na uwadze, edukacja seksualna winna być dostosowana do wieku, stopnia rozwoju młodych osób i zdolności ich rozumienia. Rezultat takiej edukacji podkreśla znaczący wpływ społeczno-kulturowy tożsamości płciowej ${ }^{29}$.

Obecnie wyróżnia się trzy orientacje seksualne: heteroseksualną (najbardziej rozpowszechnioną wśród populacji), homoseksualną i biseksualną. Bardziej właściwe jest pojęcie tożsamości seksualnej, która akcentuje podmiotowość i subiektywność w określaniu własnej płci. Prawdopodobnie w przyszłości zostaną wyodrębnione dwie kolejne orientacje seksualne: aseksualna (obejmuje ok. 1,3\% populacji) oraz autoerotyczna ${ }^{30}$.

W tym miejscu warto przywołać model Seligmana, który dotyczy rozwoju seksualności. Wartość tego modelu polega na uporządkowaniu różnych pojęć. Obejmuję on pięć kategorii:

- tożsamość seksualną;

- orientację seksualną;

- preferencje i zainteresowania seksualne;

- rolę płciową

- funkcjonowanie seksualne.

Seksualność wiąże się z jej funkcją prokreacyjną i kompensacyjną, a także przeżyciami i zachowaniami seksualnymi, relacjami partnerskimi, instytucjonalizacją seksualności. Rzeczowo, obiektywnie i merytorycznie prowadzona edukacja seksualna będzie tworzyła klimat tolerancji, otwartości i szacunku w odniesieniu do seksualności

29 Coraz więcej badaczy krytycznie ocenia pojęcie orientacji seksualnej, ponieważ niejasne są kryteria jej rozpoznawania, bywa zmienna w ciągu życia, subiektywnie rozumiana i jest wytworem języka, uproszczonej kategoryzacji społecznej.

$30 \quad$ Z. Lew-Starowicz, Seksuologia psychospoteczna, dz. cyt., s. 27. 
człowieka, różnych stylów życia i wartości. Winna przekazywać informacje o fizycznych, kognitywnych, społecznych, emocjonalnych i kulturowych aspektach seksualności, antykoncepcji, zapobieganiu chorobom przenoszonym drogą płciową i HIV, a także o wymuszeniach seksualnych.

Edukacja seksualna rozpoczyna się we wczesnym dzieciństwie i prowadzona jest dalej w okresie młodzieńczym oraz w okresie dorosłości. W przypadku dzieci i młodzieży jej celem jest wspieranie i ochrona rozwoju seksualnego. Edukacja seksualna stopniowo wyposaża dzieci i młode osoby oraz daje im możliwość zdobycia informacji, umiejętności i pozytywnych wartości, umożliwiając zrozumienie i cieszenie się własną seksualnością, tworzenie bezpiecznych i spełnionych związków, a także podjęcie odpowiedzialności za zdrowie seksualne i dobre samopoczucie zarówno własne, jak również innych osób.

Odpowiednia edukacja seksualna umożliwia dokonywanie wyborów poprawiających jakość życia i przyczyniających się do stworzenia wrażliwego i sprawiedliwego społeczeństwa. Dzieci i młodzież mają prawo do dostosowanej do ich wieku edukacji seksualnej. Podstawowym celem edukacji seksualnej jest skupienie się na seksualności jako pozytywnym ludzkim potencjale i źródle satysfakcji oraz przyjemności. Jasno uznawana potrzeba zdobycia wiedzy i umiejętności niezbędnych do zapobiegania chorobom przenoszonym drogą płciową staje się celem drugorzędnym w stosunku do tego ogólnie pozytywnego podejścia. Co więcej, edukacja seksualna powinna odwoływać się do zaakceptowanych na arenie międzynarodowej praw człowieka, a w szczególności prawa do wiedzy na temat własnej seksualności.

W podsumowaniu należy zwrócić uwagę na fakt, że prawidłowy rozwój psychoseksualny dziecka i adolescenta trzeba rozpatrywać w aspektach biologicznym i psychologicznym. Jego fizjologiczny przebieg daje możliwość prawidłowego funkcjonowania dziecka, a następnie adolescenta $\mathrm{w}$ życiu dorosłym ze wszystkimi tego konsekwencjami. Dlatego tak ważna jest nie tylko znajomość 
poszczególnych etapów rozwoju psychoseksualnego, a przede wszystkim rozumienie z nimi związanych zachowań dziecka czy dorastającego. Rozumienie to daje szansę młodemu rozwijającemu się człowiekowi, że jego zachowania zostaną prawidłowo odczytane i zinterpretowane, a w razie potrzeby czy trudności otrzyma on fachową pomoc. Niektóre zachowania seksualne mogą bowiem towarzyszyć rozładowaniu emocji i lęków związanych z traumą nadużycia lub porzucenia i niekoniecznie muszą świadczyć o patologii dziecka w obszarze jego seksualności. Aby udzielić pomocy lub wykluczyć zaburzenie, należy znać etapy rozwoju psychoseksualnego i umieć interpretować zachowania dziecięce, dlatego autor przygotował niniejszy artykuł głównie dla potrzeb edukacyjnych.

\section{Bibliografia}

Beer U., Ajednak mitość..., tłum. B. Kocowska, Zakład Narodowy im. Ossolińskich, Wrocław 1991.

Beisert M., W poszukiwaniu modelu seksualności cztowieka, w: Seksualność w cyklu życia cztowieka, red. M. Beisert, Wydawnictwo Naukowe PWN, Warszawa 2006, s. 7-28.

Drozdowski P., Kokoszka A., Podstawowe pojęcia psychoanalizy. w: Wprowadzenie do psychoterapii, red. P. Drozdowski, A. Kokoszka, Akademia Medyczna im. M. Kopernika, Kraków 1993, s. 59-76.

Freud S., Życie seksualne, tłum. R. Reszke, Wydawnictwo KR, Warszawa 1999.

Imieliński K., Cztowiek i seks, Instytut Wydawniczy Związków Zawodowych, Warszawa 1986.

Imieliński K. (red.), Seksuologia - zarys encyklopedyczny, PWN, Warszawa 1985.

Kernberg O.F., Zwiazki mitosne. Norma i patologia, tłum. E. Lipska, Zysk i S-ka, Poznań 1998.

Lew-Starowicz Z., Seksuologia psychospoteczna, w: Podstawy seksuologii, red. Z. Lew-Starowcz, V. Skrzypulec, Wydawnictwo Lekarskie PZWL, Warszawa 2015, s. 25-33.

Obuchowska I., Jaczewski A., Rozwój erotyczny, Wydawnictwo Akademickie „Żak”, Warszawa 2002.

Sadock B.J., Sadock V.A., Kaplan and Sadock's Pocket Handbook of Clinical Psychiatry, Fifth edition, Lippincott Williams and Wilkins, Philadelphia (PA) 2010.

Seidman S., Spoteczne tworzenie seksualności, tłum. P. Tomanek, Wydawnictwo Naukowe PWN, Warszawa 2012. 
Standardy edukacji seksualnej w Europie. Podstawowe zalecenia dla decydentów oraz specjalistów zajmujących się edukacją $i$ zdrowiem, <http://www.federa. org.pl/dokumenty_pdf/edukacja/WHO_BZgA_Standardy_edukacji_ seksualnej.pdf> [dostęp: 12.10.2016].

\section{ADRES DO KORESPONDENCJI:}

\section{Dr Marcin Welenc}

Uniwersytet Gdański

Wydział Nauk Społecznych

pedmw@ug.edu.pl 